\title{
THE ROLE OF GRASSLAND IN MANAGEMENT
}

\section{S. J. MORROW}

Farmer, N o. 3, R.D., Ashburton

THIS PAPER will describe the role of grassland in the management of an intensive, heavy land, mixed cropping unit farmed in conjunction with a block of light land three miles away. The homestead block of 276 acres was part of the Longbeach estate and was bought by the Crown in 1950. The writer began farming it in March, 1951. The soil is a Temuka heavy silt loam with 5 to 8 in. of topsoil on 15 to $30 \mathrm{in}$. of clay over shingle and clay. It is extensive ly tile-drained by the original Longbeach system but still has wet gullies which are difficult to drain and a hindrance to cultivation.

In 1961,319 acres of undeveloped light land was bought. This is a Lismore verp stony silt loam with 5 to 6 in. of stony topsoil on shingle. Severe drying-out occurs in summer, but in perhaps one year in six when the water-table is high it is subject to undercurrents. The Government unimproved value of both blocks is \$74 an acre. Rainfall averages $24 \mathrm{in}$. The homestead block has water available from the catchment board and internal drains for sprinkler irrigation, but as yet there is no irrigation on the light land. The labour force consists of the writer, a married man, and a student from August to February.

For the first three-years the farm carried 500 ewes and crops averaged 30 acres each of wheat, linseed and 'Grasslands Manawa' ryegrass. When the light-land was bought, stock numbers were 1,200 ewes and 300 to 400 hoggets bought in each autumn, with the crop acreage about the same. The rotation was old pasture $\rightarrow$ Manawa $\rightarrow$ linseed $\rightarrow$ wheat $\rightarrow$ sow down, and five years' grazing. All grass was closed for autumn-saved pasture except paddocks to be broken up and the problem of standing sheep on these through a wet winter and lambing was a muddy one indeed. In November the paddocks were ploughed, fallowed to February and sown to Manawa and turnips. This provided a large amount of feed before being closed for ryegrass seed in late October. The first year pastures tollowing wheat were grazed to avoid the smothering effect heavy seed. crops were having on clover and ryegrass and some high-producing pastures were obtained. 


\section{DEVELOPMENT OF THE LIGHT LAND}

With the purchase of the Plains block, wintering was much easier. To keep winter stock numbers as high as possible, butchers' hoggets were carried for several years. To clean the browntop-sweet vernal pastures, two summer fallows with Manawa and turnips between were used, the paddock being ploughed before the annual weed grasses had seeded.

By 1965 the whole farm had been resown, fenced from 3 to 12 paddocks and stock water provided. The present rotation is from old pasture $\rightarrow$ Manawa and turnips $\rightarrow$ turnips $\rightarrow$ peas $\rightarrow$ sow down, a period of about 26 months out of grass during which time the paddock receives two short summer fallows, a spring cultivation for peas, and a quick working for sowing down in February.

The seed mixture is 1 bushel perennial ryegrass, $3 \mathrm{lb}$ 'Grasslands Huia' white clover, 2 lb 'Grasslands Turoa' Montgomery red clover, and 2 lb 'Grasslands Apanui' cocksfoot with $4 \mathrm{oz}$ turnips. Swedes have been grown but discarded in favour of turnips which allow longer use of the paddock before cultivation.

From 300 ewes and their lambs in the first spring, this year it is planned to leave 1,300 ewes and 540 hoggets on spring grazing, take at least one cut of hay from the 50 acres of lucerne, and harvest 26 acres of peas.

\section{STOCK AND PASTURE MANAGEMENT}

Present stock numbers are 540 hoggets and 1,760 ewes of which half go to the Romneg ram, the balance going to the Southdown and South-Dorset Down. Depending upon rainfall, flushing and tupping are done on saved paddocks on the Plains and irrigated white clover and Manawa at home. When the rams have been out three weeks, feeding level is gradually lowered and about 170 acres on the light land progressively closed for autumnsaved pasture. The ewes are then put on paddocks at home which are to be sloughed for spring crop, and are introduced gradually to ryegrass straw. During late April and May they may eat 1,500 bales. Any sheep not doing well are taken out and given better treatment with the two-tooths until early June when all ewes go to the Plains to turnips.

Winter feed on the home block is mainly fed to the hoggets which do not tramp the paddocks so much in wet conditions. Until early July the lucerne. stands which have been fed off earlier by the hoggets are used as a 
run-off for the ewes. In this case the muddier the paddocks become, the more effective is the tramping in reducing weeds like storksbill and mouse-eared chickweed. The stands are closed to stock by mid-July and in early August receive $2 \frac{1}{2}$ cwt superphosphate. The first paddock of turnips to be fed is sown to blue peas in August. Last year these yielded $\mathbf{4 1}$ bushels per acre. The aim is to have enough turnips to carry the hoggets and other dry sheep from shearing in early August to late September. This keeps them well out of the way during lambing. October is a tight period for them and they may be fed some hay until lambs are drafted and a paddock freed.

The ewes are synchronized to lamb in three mobs six days apart from the first of August. Three weeks before lambing they are drenched and gradually given fewer turnips and more grass. Three hundred of the older ewes mated to the Down rams are taken home to lamb first so that they can be drafted and weaned as paddocks are closed for ryegrass and white clover. On the Plains the best autumn-saved pastures are stocked at about 8 ewes per acre and, as paddocks even up, this is later adjusted to 6 or 7 ewes per acre. The ewes are set-stocked where possible but moved round if the feed situation requires it. The first draft of lambs is taken when the local works open in mid-October. Undrafted lambs are weaned on to lucerne from early November to shearing at the beginning of December, while the ewes go to the two paddocks which are to be chisel-ploughed for turnips. These are drilled from early January to mid-February depending on moisture.

Every effort is made to stock all paddocks which are to be cultivated with heavy concentrations of sheep for as long as possible. After shearing all ewes are returned to the light land where they are fed ryegrass straw until stubble paddocks are available in February. Two cwt of superphosphate is then applied to all Plains pastures and they are left to respond to the fickle Canterbury rainfall. At this stage, when growth is at a standstill, they are grazed bare and a lizard could be seen running across them from chains away. All young grass, including that sown with turnips, is grazed by lambs and not allowed to become rank. A bout 3,000 bales of lucerne and 3,000 of ryegrass straw are saved each year.

\section{STOCK PRODUCTION}

Lambing averages $125 \%$ with $75 \%$ of Downs and $50 \%$ of Romneys drafted fat off the mothers. Average weight 
is $31 \mathrm{lb}$. Ewes average $10.5 \mathrm{lb}$ of wool and the young sheep $4 \mathrm{lb}$ as lambs, $6.4 \mathrm{lb}$ in August and $6 \mathrm{lb}$ as two-tooths in January.

Stock management therefore aims at maintaining the balance of fertility between light land and heavy by the transfer of stock as seasonal and feed fluctuations demand.

\section{CROPPING PROGRAMME}

The purchase of the light land marked the beginning of more intensive cropping on the heavy land since extra income was needed to meet loan commitments and it was felt there had been a fertility build-up which could be exploited. Of an effective acreage of 258, Table 1 shows land utilization for this season and last.

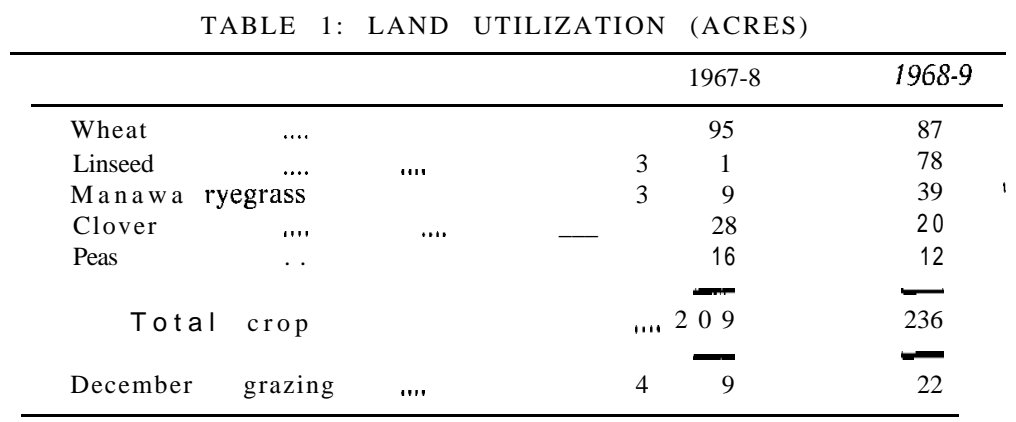

There is no fixed rotation. Basically, it revolves around maximum acreages of wheat and linseed with white clover and more recently peas as restorative crops, and Manawa for seed and to provide standing room for sheep. The Manawa pastures are left down only two or three years. Results would indicate that, with heavy stock concentrations, this is long enough to rebuild fertility to a reasonable level. In fact, for maximum crop yields it can probably be rebuilt to too high a level. Often in a linseed $\rightarrow$ wheat $\rightarrow$ linseed rotation the second crop of linseed has outyielded the first by several hundredweight. Pastures are either ploughed after shearing and given a short fallow before going to Manawa and turnips in February, or ploughed from May to August for linseed. Manawa has averaged 20 bushels more grown in this way than after wheat at the end of a rotation. If the present low price of this seed continues, only this method will be used in future, grazing the first year grass after wheat. This will give better pastures and a quicker fertility build-up. The harvested 
specialist Manawa and white clover paddocks, after heavy autumn and winter stocking, go to either wheat or linseed. I have a theory that a much greater nitrogen build-up is obtained by heavy stocking at this time of the year than under dry summer conditions.

Wheat is sown from mid-May to mid-June, but in this past extremely wet season, for the first time in 17 years, almost all of the wheat has had to be spring sown. Second crops are avoided as much as possible. Hilgendorf, which comprises on average two-thirds of the area, has regularly outyielded A otea. Linseed is sown in early October, although this year it is intended to sow a late crop after drafting and weaning the lambs from the paddock. The old ewes will be shorn and sent to the works and I may irrigate before ploughing to ensure a good seed-bed. In the past the paddocks going from wheat to linseed have been fallowed throueh the winter, but last year one was sown to Manawa and turnips and one to rape for feed. From the feed point of view, the Manawa was more successful and it remains to be seen whether this later cultivation will affect the linseed yield.

To maintain maximum wheat and linseed acreages and yields, white clover sown with linseed was introduced into the rotation three years ago. In contrast to earlier years when the clover grew leaf only, reasonable crops of seed have been harvested and the following cash crops yielded well. Although this is not ideal land for peas, garden peas were tried last year, with disappointing results. A better drained paddock is in Blue peas this year.

The following typical rotations showing yields illustrate some of the points mentioned:

77 bushels M.D. Manawa-26.5 cwt linseed-75 bushels Hilgendorf wheat-29.5 cwt linseed-395 lb M.D. white clover-75 bushels Hilgendorf wheat-Manawa.

30 cwt linseed-77 bushels Aotea wheat-60 bushels spring wheat-29.5 cwt linseed-350 lb M.D. white clover30 cwt linseed-wheat.

68 bushels M.D. Manawa-94 bushels Aotea wheat-3 years pasture-30 cwt linseed-86 bushels Hilgendorf-89 bushels Aotea-41 bushels M.D. Manawa.

2.

Average yields over the past five years are given in Table 
TABLE 2: AVERAGE YIELDS 1963-4 TO 1967-8

\begin{tabular}{lll}
\hline Wheat .... & $\ldots \ldots$ & 72 bushels \\
Linseed .... & 27.3 cwt \\
Manawa ex fallow & 69 bushels M.D. \\
Manawa ex wheat & 48 bushels M.D. \\
Clover $\ldots$ & & 4.328 lb M.D. \\
Peas $\ldots . .$. & & 40 bushels \\
Barley & & 11 bushels \\
\hline
\end{tabular}

\section{FERT I LIZER}

Superphosphate is not used on first crops of wheat or linseed but second crops receive 1 to $1 \frac{112}{2}$ cwt. Pastures receive 2 to $21 / 2$ cwt in the autumn and 2 cwt of ammoniated superphosphate is used when sowing down after wheat. One ton of lime is applied before sowing down and also, if required, before sowing white clover or peas. Ryegrass seed crops get $50 \mathrm{lb}$ of nitrogen after closing and worthwhile responses have been obtained from the use of nitrogen on some second crops of wheat.

\section{WEEDS AND PASTURE PESTS}

Nodding thistle is the main weed on the light land but first-year spraying to prevent any flowering and follow-up back bending with grubber in hand, almost succeeds in controlling it. On the heavy land, wild oats are increasing and if unable to be controlled could seriously disrupt the cropping programme. Wireweed and cornbind are difficult to control in linseed when it is undersown with white clover and one of the less effective sprays must be used.

Paddocks harvested for Manawa and white clover are usually badly infested with porina caterpillar and if not to be ploughed are sprayed. On the light land DDT is used in alternate years and, although some grass grub and porina damage occurs in most years, so far this has not been of serious proportions.

\section{IRRIG ATIO N}

Irrigation has been used for ten years and this plays a very important part in eliminating seasonal variations and maintaining a steady level of production. Possession of an irrigation plant allows planning and budgeting to be carried out with confidence and takes much of the uncertainty out of cropping and the growing of small seeds. It allows late closing for seed and late cultivation for spring crops after early weaning of lambs. In dry 
seasons, ryegrass yields have been increased by as much as $50 \%$ and linseed can be depended on to yield at least $25 \mathrm{cwt}$. The irrigation may also be used on white clover and peas, to ensure good establishment after wheat and quick recovery of ryegrass and clover after harvest or to provide fattening and flushing feed. In fact, with it almost any programme can be planned with full confidence that it can be carried through.

\section{THE FUTURE}

What of the future? I shall continue to use stock and grassland as a means to increase crop yields, and intensify the production of proven crops in preference to diversification, provided the markets are there. I am confident that, with the use of sound fertility-building practices and the application of further scientific know-how, present production will increase.

Using average yields and last season's prices, and not including returns from stock, this year's heavy land crop and small seeds area would give a gross profit of $\$ 105$ per acre or a gross margin of over $\$ 80$ per acre. I think these figures and the fact that crop yields are being maintained and the fertility of the light land built up justify the use of these methods, and find in them a challenging, stimulating and sufficiently rewarding way of farming.

\section{DISCUSSION}

On being asked if he might use Ariki ryegrass in the future seeing that he had been sowing Ruanui and Manawa, Morrow stated that Ruanui was. used only on light land and Manawa on heavy land. The two were never mixed. He considered it would be difficult to change to Ariki because of the risk of contamination. To a comment that the yields of Hilgendorf wheat obtained by him were rather high, Morrow agreed that it was unusual to obtain such yields in mid-Canterbury from Hilgendorf. $\mathrm{He}$ could suggest no good reason to account for this. 